\title{
The Influence of Visualization of Food Appearance and Food Quality Towards Customer Satisfaction in Tutup Panci Bistro, Bumi Serpong Damai, South Tangerang
}

\author{
Aditya Nova Putra ${ }^{1}$, Saptarining Wulan' ${ }^{2}$, Rahmat Ingkadijaya ${ }^{3}$ \\ 1,2,3 Sekolah Tinggi Pariwisata Trisakti \\ 1aditya.nova01@gmail.com
}

\begin{abstract}
Nowadays, Visualization of food appearance has become an important factor in influencing customer satisfaction which is creating an unforgettable experience when people visit to the restaurant. The aspect of visualizing the appearance of food must also be balanced by good food quality in the restaurant. The purpose of this study was to identify the effect of visualization of food appearance and food quality in achieving customer satisfaction in Tutup Panci Bistro. In this study, visualization of food appearance has five important factors that support in achieving customer satisfaction, which are; component of the material used, color selection, food texture, shape and size, and layout. Therefore, in previous study, quality of food has three important factors, which are: the taste of food, the variety of menus, and the nutritional content of food. The methodology used in this study was quantitative and qualitative, whereas, quantitative data collection was obtained through questionnaires to 100 guests at Tutup Panci Bistro. Meanwhile, qualitative data is obtained through interviews with food influencers / reviewers. Based on the results obtained, appearance and quality of food have a significant positivity influence towards customer satisfaction at Tutup Panci Bistro.
\end{abstract}

Keywords: Visualization of food appearance, Quality of food, Customer Satisfaction 
The Influence Visual of Food Appearance and Food Quality towards Customer Satisfaction in Tutup Panci Bistro, Bumi Serpong Damai, South Tangerang

\section{A. Introduction}

The rapid development of the restaurant business today makes restaurant owner needs to compete for making a unique concepts and atmosphere in order to grab a new market. Especially, the development number of restaurant businesses established in Bumi Serpong Damai area is one of the challenge for restaurant owner to always think of a unique concept with marketing such as; discount promotions, music entertainment, and followed by unique food and beverage products. In addition, restaurant owners must be able to think about food appearance that can be used as a one factor in attracting consumers to come into the restaurant. Based on previous research, the quality of the product, the quality of service offered, and the atmosphere of the business location, the price of the product and the services provided are as several factors that can affect customer satisfaction in restaurant (Grimsley, 2012). Looking at the current trends as the millennial generation, people's desire to come to a restaurant is to get their food which is having a good appearance in its visualization. As the result, the food which has a good appearance will increase the desire of consumers to take pictures of the food and upload the photos on their social media. These customers override the price and taste aspects of food, and want to pay more to find a new experience for a good presentation in food that they perceived in restaurant (Carlos \& Carles, 2016).

If the nice visual appearance of food can be balanced with the good quality of food and the price is worth it by customers, the satisfaction of customers in restaurant would be occurred. Ketaren (2017), stated, owner of restaurant businesses tends to ignore their visual of food appearance. They will more prioritize the aspect of their food taste. They put taste above the other aspects. They also sometimes are busier talking about other restaurants that are more crowded than those they manage themselves and forget to compare the "customer experience" provided by other parties compared to what they run. Customers when they choose to come to the restaurant, they absolutely do not buy the products but they are seeking more value, which is an experiences that they are not be able to obtain in other restaurant. But slowly without realizing it, visual food appearance has become a sensational experience for customer where eating is a sensuous experience (Ketaren, 2017). 
The Influence Visual of Food Appearance and Food Quality towards Customer Satisfaction in Tutup Panci Bistro, Bumi Serpong Damai, South Tangerang

\section{B. Literature Review}

\section{Visual of Food Appearance}

Food Presentation or food appearance is an art of processing, organizing, and decorating a food in a dish that is served to increase visual appeal. When serving a meal to consumers, always remember that people will always eat it with their eyes before eating it (Hause \& Labensky, 2006). As the starting point in restaurant of planning is to design "customer experience in every single contact point" or the experience that customers want to experience in every contact that occurs. This perceived experience encompasses all five senses, which are seen, those that are kissed, touched, or tasted (Ketaren, 2017). The appearance of a food on a plate is one aspect that consumers seek to achieve their expectations of an experience when it comes to a restaurant. Food which has a good appearance or presentation would be adding a value on a plate that will be serving to the guest who buy the food. Chow, et. al (2013) states that the appearance of a food can be seen physically and the product can look good quality if the food is served with attractive packaging or added with a label of information about the product.

The appearance of a food is the process that offered to the guest who will enjoy food in a visually appealing way where it can have a significant impact on consumers while enjoying their food. (Chow, et. Al., 2013). A good composition in a food presentation that is presented includes balance such as: selection of the right ingredients, different colors, texture, shape, and arrangement or layout. This composition can be further enhanced by decorating a food on a plate with decoration, crumbs, or sauce. Some techniques such as decorating dishes with powdered sugar do not affect the taste of food substantially, they only make one finish look more attractive (Caribean Hotel Association, 2013). In addition, appearance can have a "wow" effect that changes the perception of taste and subsequent food acceptance. So from that interesting, neat visual appeal will give a good first impression for them to achieve satisfaction when it comes to a restaurant (Amanda Ray, 2015).

\section{Food Quality}

Food quality in a restaurant is certainly has become an important factor that affect customer satisfaction in a restaurant. The quality of the food is the value, conformity with a specific specification or requirement, or also the suitability of benefits. In addition, quality is explained as a satisfying consumer so that every quality development effort must begin from understanding consumer perceptions and needs (Wahyu, et al. 2013). According to previous research, Ahmad (2015), found that food quality was the main factor for 
The Influence Visual of Food Appearance and Food Quality towards Customer Satisfaction in Tutup Panci Bistro, Bumi Serpong Damai, South Tangerang

someone decided to come to a restaurant. However, there are more value components to be offered by customers, such as; quality of service, an appropriate price, and a good physical environment or restaurant atmosphere will make a restaurant the main choice to be visited by customers. Visual good appearance in a food is one of the elements of the quality of food offered by restaurants. The appearance of food is one of the visual attractions to increase their appetite in the beginning after the food on a plate is served.

For restaurant business owners, it becomes a challenge that they must be able to make food quality as the main factor that must be considered first before paying attention to other factors (Ahmad, 2015). Hiring expert cooks is one way that a restaurant can provide good quality food for its visitors. Jooyen $\mathrm{Ha}$ (2010), said that the factors that can influence a food quality in a restaurant are the taste of food, the varied menu, and the nutritional content that is in a food. These three factors can be used as reference as an aspect that can achieve customer satisfaction in the restaurant industry.

\section{Customer Satisfaction}

Nowadays, every business will concentrate on how to provide more value to every customer who pays for the products and services offered by the company. Satisfaction for consumers who come to a restaurant can be judged as the main to make them repeat the purchase of products that they consider satisfied (Exhibition, Moizer, \& Pettinchior, 2010). When a customer feels satisfied then the customer can re-buy again even the customer will share a happy experience to their relatives for the results that satisfy him after consuming the product (Septiani and Sulistio, 2018). If the loyal customers are able to be created, there will be repeat purchase and it will be made an advantage to the company. Loyal customers will be an advantage for a business because the company does not have to spend a lot of money to attract new customers. Customer satisfaction will promote to others about the experience provided through the power of mouth and of course a business will have a sustainable period in getting customers (Okumu, 2012).

After years, the hospitality industry has considered that customer satisfaction is an important aspect to be considered in a very difficult business competition. The ability to accurately assess customer satisfaction is a challenge in the hospitality industry (Liwei \& Pinying, 2013). Based on statements from Kotler \& Keller (2009), customer satisfaction is interpreted as a consumer's feeling based on the pleasure or disappointment of the results of product performance and services provided to the customer's initial expectations.

Satisfaction for consumers who come to a restaurant is valued as a virtue to make them repeat the purchase of products because they are considered satisfied (Exhibition, Moizer, \& Pettinchior, 2010). Therefore, 
The Influence Visual of Food Appearance and Food Quality towards Customer Satisfaction in Tutup Panci Bistro, Bumi Serpong Damai, South Tangerang

customer satisfaction refers to perceived evaluation of the difference between expectations expected with the actual performance of a product that is felt for consumers. If customers are satisfied with the products and services of the company, the company will maintain it because it is considered the most significant aspect and approaches the success of an achievement. Customer satisfaction is defined as the way customers perceive and assess performance, which is ongoing (Gustafsson, Johnson \& Roos, 2005). The big challenge in maintaining a business in the present era is that everyone wants to always get something new. Changes in business, especially restaurants, now have created a perception by every business owner to be able to create something new in a restaurant to fulfill every needs and wants for every consumer. It can be no longer rely on a delicious food in every restaurant, but aspects of service, cleanliness, uniqueness become a trend that must always be fulfilled by every business owner to create customer satisfaction (Ghimire, 2012).

\section{Research Model}

With the above mentioned literature, the relationships among potential variables and indicators can be illustrated in the following research model.

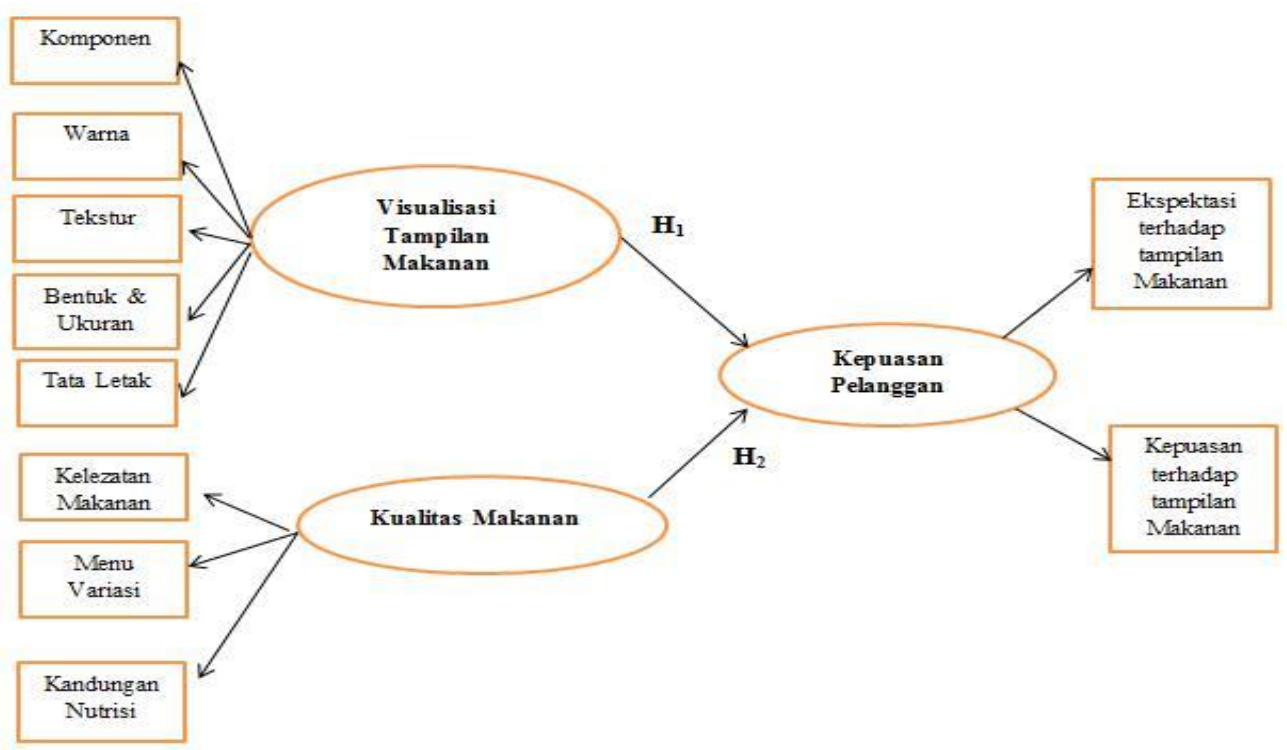

Figure 1. Research Model

As illustrated of research model said that the Visual of Food Appearance variable has five indicators that represent, namely: components, color, texture, shape \& size, and layout. In addition, the Food Quality variable has three indicators that represent, namely: food delicacy / taste, menu variation, and nutritional content. Variable Customer Satisfaction has two indicators, namely Expectation of Food Appearance and Satisfaction towards 
The Influence Visual of Food Appearance and Food Quality towards Customer Satisfaction in Tutup Panci Bistro, Bumi Serpong Damai, South Tangerang

Food Quality. In this study will look for the relationship between visualization of the appearance of food and quality of food to customer satisfaction in Tutup Panci Bistro.

\section{Hypothesis}

$\mathbf{H 1} 1_{1:}$ There is significant positive influence between visual of food appearance and customer satisfaction in Tutup Panci Bistro.

H10: There is no significant positive influence between visual of food appearance and customer satisfaction in Tutup Panci Bistro.

H21: There is significant positive influence between food quality and customer satisfaction in Tutup Panci Bistro.

H20: There is no significant positive influence between food quality and customer satisfaction in Tutup Panci Bistro.

\section{Research Method}

This study relies on the geographically-cluster sampling method to separate countless of restaurants within the proximity of the city of BSD areas. Therefore, this research is continually with non-probability sampling method which is using Convenience Sampling where the questionnaires were distributed to the customers who come to Tutup Panci Bistro.

The following table shows that assuming that only $50 \%$ of the targeted population meets the criteria while maintaining 10\% sampling error, and 95\% confidence, the minimum numbers of sample should be 97 respondents.

Table 1. Sample Size Determination

\begin{tabular}{|c|c|}
\hline \multicolumn{2}{|l|}{ Data } \\
\hline Estimate of True Population & 0.5 \\
\hline Sampling Error & 0.1 \\
\hline Confidence Level & $95 \%$ \\
\hline \multicolumn{2}{|l|}{ Intermediate Calculation } \\
\hline Z value & -1.9600 \\
\hline Calculated Sample Size & 96.0365 \\
\hline \multicolumn{2}{|l|}{ Result } \\
\hline Sample Size Needed & 97 \\
\hline
\end{tabular}

As previously mentioned, the variables and indicators used in this study are: Visual of Food Appearance (1), Food Quality (2), and seeks the influence towards Customer Satisfaction (3). 
The Influence Visual of Food Appearance and Food Quality towards Customer Satisfaction in Tutup Panci Bistro, Bumi Serpong Damai, South Tangerang

The analysis data will use SPSS for seeking validity and reliability by using Pre Test which just only distributed for 30 respondents at the first time and Post Test for 100 respondents in Tutup Panci Bistro. The relational analysis in this study follows the structural equation modeling (SEM) to examine the simultaneous occurrence of all pre-determined variables and indicators (Arbuckle, 2011; Ghozali, 2004; Santoso, 2009). It is expected that the variables and indicators provide insights on the degrees of influence.

\section{Results \& Discussions}

\section{Respondents' Characteristics}

The preliminary frequency-based data analysis reveals the following information on the respondents' characteristics from 100 respondents which are the guest who visit Tutup Panci Bistro are; approximately 68\% of respondents are female and $32 \%$ are male, the percentage of $68 \%$ is dominated by range of $15-30,30 \%$ respondents are employee, $27 \%$ are housewife, $22 \%$ are entrepreneurs, just only $17 \%$ are students, $60 \%$ of the guest are spending between range IDR. 50.000 - IDR. 150.000,00.

Since it is necessary to examine the level of validity and reliability of the available data, the pre-test and post-test were conducted. The pre-test was run with only 30 data from Respondents, and the post-test was run with all the completed responses of 100 . Since the available data has been considered reliable (94\% for the pre-test and $93 \%$ for the post-test) and valid (70\% for the pre-test and $90 \%$ for the post-test) (Santoso, 2009; Sarwono, 2012; Arbuckle, 2011). The data result indicates strong valid and reliable for all data which already obtained. The following table shows the results on reliability and validity of the data.

Table 2. Validity and Reliability Tests

\begin{tabular}{|c|c|c|c|}
\cline { 3 - 4 } \multicolumn{2}{c|}{} & $\begin{array}{c}\text { Pre- } \\
\text { Test }\end{array}$ & $\begin{array}{c}\text { Post- } \\
\text { Test }\end{array}$ \\
\hline Validity & Kaiser-Meyer-Olkin Measure of Sampling & & \\
\hline Adequacy & $\mathbf{0 . 6 9 7}$ & $\mathbf{0 . 9 0 0}$ \\
\hline Reliability & Cronbach's Alpha (standardized) & $\mathbf{0 . 9 4 0}$ & $\mathbf{0 . 9 2 7}$ \\
\hline
\end{tabular}

Source: Questionnaire \& SPSS results, modified

\section{Data Analysis}

Relying on the maximum likelihood analysis of SEM, the following results were obtained: 
The Influence Visual of Food Appearance and Food Quality towards Customer Satisfaction in Tutup Panci Bistro, Bumi Serpong Damai, South Tangerang

Table 3. Criteria of Goodness of Fit

\begin{tabular}{|c|c|c|c|c|}
\hline Criteria & $\begin{array}{c}\text { According to } \\
\text { Schumaker \& Lomax } \\
\text { (2004), Wijaya (2009) }\end{array}$ & $\begin{array}{l}\text { According to } \\
\text { Ghozali (2004), } \\
\text { Santoso (2009) }\end{array}$ & $\begin{array}{l}\text { Model } \\
\text { Value }\end{array}$ & $\begin{array}{l}\text { Goodness } \\
\text { of Fit }\end{array}$ \\
\hline $\begin{array}{c}\text { RMSEA } \\
\text { (root mean square error of } \\
\text { approximation) }\end{array}$ & RMSEA $\leq 0.08=$ better & $\begin{array}{l}\text { RMSEA } \leq 5= \\
\text { better }\end{array}$ & 0,207 & Acceptable \\
\hline $\begin{array}{c}\text { GFI } \\
\text { (goodness of fit index) } \\
\text { AGFI }\end{array}$ & $\begin{array}{c}\text { GFI value closer to } 1= \\
\text { better }\end{array}$ & $\begin{array}{l}\text { GFI value closer to } \\
1=\text { better }\end{array}$ & 0,829 & Acceptable \\
\hline $\begin{array}{l}\text { (adjusted goodness of fit } \\
\text { index) }\end{array}$ & $\begin{array}{c}\text { AGFI value closer to } 1= \\
\text { better }\end{array}$ & $\begin{array}{c}\mathrm{AGFI} \geq 0.09= \\
\text { better }\end{array}$ & 0.714 & Acceptable \\
\hline $\begin{array}{c}\text { TLI } \\
\text { (Tucker-Lewis index) }\end{array}$ & $\begin{array}{c}\text { TLI value closer to } 1= \\
\text { better }\end{array}$ & $\mathrm{TLI} \geq 0.09=$ better & 0.756 & Acceptable \\
\hline $\begin{array}{c}\text { CFI } \\
\text { (comparative fit index) }\end{array}$ & $\begin{array}{c}\mathrm{CFI} \text { value closer to } 1= \\
\text { better }\end{array}$ & $\begin{array}{c}\text { CFI value closer to } \\
1=\text { better }\end{array}$ & 0.821 & Acceptable \\
\hline $\begin{array}{c}\text { NFI } \\
\text { (normal fit index) }\end{array}$ & 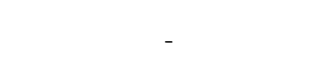 & $\mathrm{NFI} \geq 0.09=$ better & 0.792 & Acceptable \\
\hline Reliability & $\begin{array}{c}\text { Reliability } \geq 0.70= \\
\text { better }\end{array}$ & $\begin{array}{c}\text { Reliability } \geq 0.70= \\
\text { better }\end{array}$ & 0.927 & Acceptable \\
\hline
\end{tabular}

With the above measurements, the structural equation can be shown as follows;

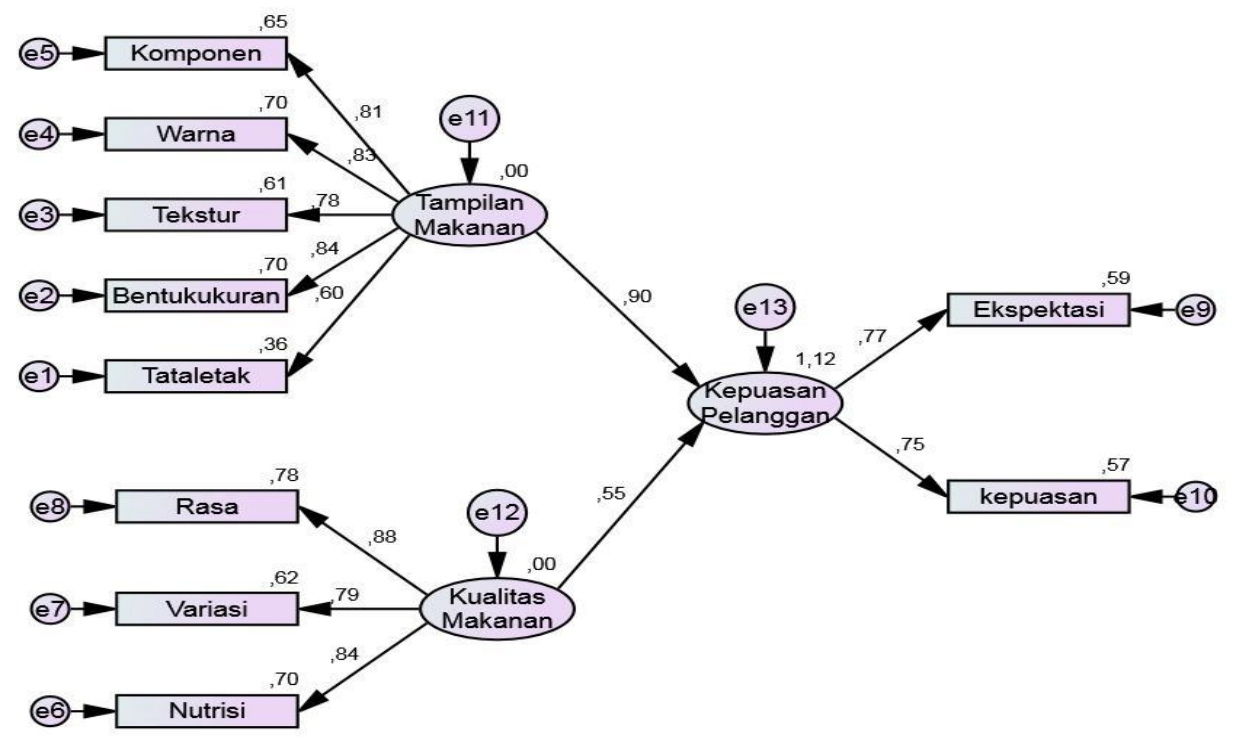

Figure 2. Structural Estimates

From the above structural estimates, the following analysis can be elaborated:

- Visual of food appearance variable has significant positive influences to customer satisfaction variable with $90 \%$ explanatory power. The value of visual food appearance has becoming significant aspect that need to be considered for restaurant business that has been revealed in this 
The Influence Visual of Food Appearance and Food Quality towards Customer Satisfaction in Tutup Panci Bistro, Bumi Serpong Damai, South Tangerang

research. All indicators of food appearance have shown positive explanatory power, which are: component has $81 \%$, Color has $83 \%$, texture $78 \%$, Size \& shape has $87 \%$, and layout has $60 \%$ toward visual of food appearance. Similar like Ketaren (2017) stated, food appearance is the first way to design customer experience when they visit the restaurant, where all five senses are used in order to achieve customer satisfaction in restaurant. Tutup Panci Bistro concern for an appropriate food appearance while serving their Indonesian fusion cuisine where focusing on food quality and their appearances.

- Food quality variable has 55\% explanatory power towards customer satisfaction in Tutup Panci Bistro. Instead of the value indicates less small rather than food appearances, therefor it still shows positive significant value. The reason is the respondents which are the guest who visit Tutup Panci Bistro already become a loyal customers and they already know about the quality of food. The customers are expected more than a good taste which is experience of their dining and nice food appearance is one way to achieve their experience. Indicators representative from food quality variable also show a positive explanatory power towards its variable, whereas: taste of food has $88 \%$, variety of menu has $79 \%$, and nutritional content has $84 \%$ toward food quality. As the result, it similar like Grimsley (2012) stated, the customers who visit the restaurant are seeking the differentiation whereas food quality and food appearance must be well balanced in order to achieve an unforgettable their dining experience in restaurant.

With the above results and with regards to the hypothesis in this study, the hypothesis tests can be addressed as follows;

Table 4. Hypothesis Tests

\begin{tabular}{|c|l|c|c|}
\cline { 2 - 4 } \multicolumn{1}{c|}{ Hypothesis } & Results & $\begin{array}{c}\text { Regression } \\
\text { Weight } \\
\text { (Maximum } \\
\text { Likelihood) }\end{array}$ \\
\hline \multirow{3}{*}{$\mathrm{H}_{1} \quad: \begin{array}{l}\text { Visual of food appearance positively } \\
\text { influences significantly toward } \\
\text { customer satisfaction }\end{array}$} & $\mathrm{H}_{1}$ is accepted & 0.904 \\
\cline { 2 - 4 } $\mathrm{H}_{2} \quad: \begin{array}{l}\text { Food quality positively influences } \\
\text { significantly toward customer } \\
\text { satisfaction }\end{array}$ & $\mathrm{H}_{2}$ is accepted & 0.550 \\
\hline
\end{tabular}


The Influence Visual of Food Appearance and Food Quality towards Customer Satisfaction in Tutup Panci Bistro, Bumi Serpong Damai, South Tangerang

\section{E. Conclusions and Recommendations}

This study concludes that all of the variables used show positive influence toward the customer satisfaction in Tutup Panci Bistro. All of the indicators also show positive explanatory power toward the variable of visual of food appearance, food quality and customer satisfaction. With the results show visual of food appearance has $90 \%$ explanatory power and food quality has $55 \%$ explanatory power toward customer satisfaction means the product that offered to customer which has a value differentiation that the competitor doesn't have will be one of advantage for restaurant business, whereas, good visual of food appearances that can be balanced with a good food quality product.

This research also can be recommended for all entrepreneurs who wants to established their own business, especially, restaurant business where they must be corporate with a good chef in order to create an appropriate balance between visual of food appearance and food quality. Hospitality industry also needs to be concerned about visual of food appearance where focusing on component, color, texture, size \& shaped, and layout. Last but not least, this study can be useful for management of Tutup Panci Bistro where they must be kept innovating a new products which has a good visual of food appearance while teaching and do some delegation for the staff.

\section{REFERENCES}

Ahmad A. 2015. The Effect of Service and Food Quality on Customer Satisfaction and Hence Customer Retention. Business Administration Department, College of Business \& Economics (CBE), Qassim University, Kingdom of Saudi Arabia.

Anantadjaya, Samuel Prasetya Dharmatama, Neneng Djuaeriah, and Innge S. Handojo. (2011a). Entrepreneurs' Accountability: Is It Accounting or Behavioral Issues. Proceeding, International Conference on Business and Information, Landmark Hotel, Bangkok, July 4-6, 2011, Bangkok: Thailand.

Anantadjaya, Samuel PD, B. Agus Finardi, and Irma M. Nawangwulan. (2011b). The Viability of Small/Micro Businesses in Indonesia: Implications of Entrepreneurial Mindset Development Model. Journal of Global Entrepreneurship, vol. 1, no. 1, p. 26-45.

Caribbean Hotel Association. 2003. Food Presentation General Guidelines. http://www.caribbeanhotelandtourism.com/cshae/docs/FOODPRESENTATION-MANUAL.pdf.

Carlos, V., Charles, M., Andy, W., Charles Spence. 2016. One of the importance of balance to aesthetic plating. International Journal of Gastronomy and Food Science. 
The Influence Visual of Food Appearance and Food Quality towards Customer Satisfaction in Tutup Panci Bistro, Bumi Serpong Damai, South Tangerang

Charles S., Betina P., Charles M. \& Ophelia Deloy. 2014 . Plating Manifesto (II): The art and science of plating. pence et al.; licensee BioMed Central Ltd. 2014.

Chow K., Dickson O., Tham W. \& Wong Y. 2013. Factors Influencing Dining Experience On Customer Satisfaction And Revisit Intention Among Undergraduates Towards Fast Food Restaurants. University Tunku Abdul Rahman, Faculty of Accoutancy and Management.

Ghozali, I. (2004). Model Persamaan Sktruktural: Konsep dan Aplikasi dengan program AMOS Ver. 5.0. Semarang, Jawa Tengah, Indonesia: Badan Penderbit Universitas Diponegoro.

Grimsley, $\mathrm{S}$

(2012.)

Retrieved

from

Study.com: $\quad$ http://study.com/academy/course/ceoemarketingeducation-practice-study-guide.html.

Gustafsson, A., Johnson, M. D., \& Roos, I. (2005). The Effects of Customer Satisfaction, Relationship Commitment Dimensions, and Triggers on Customer Retention. Journal of Marketing, 69(4), 210-218.

Jooyen Ha, SooCheong. 2010. Effects of service quality and food quality: The moderating role of atmospherics in an ethnic restaurant segment. International Journal of Hospitality Management 29 (2010) 520-529.

Ketaren, Indra. 2017. Apa Itu Gastronomi?, http://gastroina.blogspot.co.id/2014/08/apa-itu-keahlian-memasak.html.

Kotler, P., \& Keller, K. L. 2009. Marketing Management (13th ed.). Pearson Prentice Hall.

Labensky, S. R., \& Hause, A. M. (2006). On Cooking: A Textbook of Culinary Fundamentals (4th ed.). Pearson Prentice Hall.

Liwei, Hsu, and Pinying, Wu. 2013. Electronic-Tablet-Based Menu in a Full Service Restaurant and Customer. International Journal of Business, Humanities and Technology, Vol. 3 No. 2.

Mustafa, Z., \& Wijaya, T. 2012. Panduan Teknik Statistik SEM \& PLS dengan SPSS AMOS. Yogyakarta: Cahaya Atma Pustaka.

M. Wahyu, Handoko D. \& Sari L. 2013. Pengarub Keragaman Menu, Kualitas Produk, Citra Merek, Dan Iklan Terbadap Keputusan Pemebelian. Diponegoro Journal Of Social And Politic Tahun 2013, Hal. 1-9.

Ray, Amanda. 2015. The Art of Food Presentation. https://www.artinstitutes.edu/about/blog/food-plating-the-art-offood-presentation

Santoso, Singgih. 2009. Panduan Lengkap Menguasai Statistik dengan SPSS 17. Elex Media Komputindo: Jakarta.

Sarwono, Jonathan. (2012). Metode Riset Skripsi Pendekatan Kuantitatif. Menggunakan Prosedur SPSS (Edisi Pertama). Jakarta: PT Elex Media. Komputindo.

Schumacker, R.E., \& Lomax, R.G. 2004. A beginner's Guide to Structural Equation Modeling (2nd ed). Mahwah, NJ, USA: :awrence Erlbaum Associates. 
The Influence Visual of Food Appearance and Food Quality towards Customer Satisfaction in Tutup Panci Bistro, Bumi Serpong Damai, South Tangerang

Septiani, Thalia and Tri Joko Sulistio. 2018. The Influence of Accessibility And Facilities on Visitor Satisfaction in Mangrove Forests Pantai Indah Kapuk. Tourism Research Journal. Vol. 2, No. 1: 50 - 57.

Wijaya, T. (2009). Analisis Structural Equation Modeling Mengunakan AMOS. 